\title{
Studies on Varietal Reaction of Tuberose against Stem Rot Diseases Caused by Sclerotium rolfsii
}

\author{
P. Boopathi, M. Jayasekhar", N. Rajinimala, M. Gomathy and J. Prem Joshua \\ Department of Plant Pathology, Tamil Nadu Agricultural University AC \& RI, \\ Killikulam-628252 Thoothukudi, (India) \\ *Corresponding author
}

Keywords

Tuberose,

screening,

Sclerotium rolfsii,

basal rot or stem rot

Article Info

Accepted:

08 June 2020

Available Online:

10 July 2020

\section{A B S T R A C T}

Tuberose (Polianthus tuberosa Linn.) is a commercially important bulbous ornamental perennial plant cultivated in the world as well in India for cut and loose flower trade. Tuberose gets infected by many fungal, bacterial and viral diseases. The most devastating disease is basal stem rot caused by the fungus Sclerotium rolfsii. According to the present studies, using varietal screening method against the Sclerotium rolfsii is considered as an ecological and durable method for controlling this disease. Therefore, three different varieties and three local cultivars were evaluated by pot culture under controlled condition. Study of varietal resistance revealed that all the six cultivars tested under controlled glass house condition were found highly susceptible (HS) to stem rot or basal stem rot diseases. But some other cultivars are found low level of per cent disease incidence.

\section{Introduction}

Tuberose (Polianthus tuberosa Linn.) is a monocot, perennial, bulbous ornamental plant belonging to family Amaryllidaceae (Rose 1903-05, Baily 1939). Hutchinson (1944, 1959, 1960) placed it under the family of Agavaceae. Tuberose is a multipurpose flower which is used for floral ornaments, artistic garlands, bouquets and buttonholes or crown frequently used during marriages and religious ceremonies (Randhawa and
Mukhopdhyay, 1986). The flower is also used for the extraction of its highly valued natural flower oil which is one of the most expensive raw material of high-grade perfumes, cosmetic products (Mallavarapu, 1995).

It also contains anti-inflammatory and antispasmodic properties (Maliga, 2003).Tuberose floral essential oil are fetching higher price than the other floral essential oil. The fungal disease stem rot (Sclerotium rolfsii) is one of the most serious 
problem in tuberose cultivated areas. It causes high loss in tuberose production. The pathogen is soil borne. It causes sucker rot, stem rot, basal stem rot, rhizome rot, and as well as premature death of affected plants. Under severe condition, the losses due to stem rot disease may go up to 50-60 per cent (Kakade, 2007). In case of more severe condition, affected plant does not produce flowering shoots (Das, 1961).

In Tamil Nadu, losses estimated range from 20-40\% per cent (Theradimani et al., 2018). The pathogen produces dormant resting body (sclerotia). These resting bodies survive in soil for many years which germinate under favourable condition and infect the plants.

The objective of the present study to use immune or resistant cultivars is a long term solution to manage this disease. Therefore, the study was initiated to screen tuberose cultivars against stem rot or basal stem rot diseases.

\section{Materials and Methods}

Four different tuberose cultivars were collected from Floriculture Research station, Thovalai, Tamil Nadu and another two local cultivars were collected from farmer's field. Totally six different cultivars were used for this study. Inoculum of Sclerotium rolfsii isolated from infected plant was multiplied in sand maize medium for soil infestation. Experiment was conducted in pots at Department of Plant Pathology, AC \& RI, Killikulam. Soil was twice sterilized in autoclave at $121^{\circ} \mathrm{C}$ for $15 \mathrm{lps}$.

Then sterilized soil was filled in pots. Potted soil was inoculated with test fungi Sclerotium rolfsii multiplied in sand maize medium. Three sucker of each variety in each pot was sown after seven days incubation of soil. Before sowing tuberose suckers were surface sterilized with $1 \%$ sodium hypochlorite solution and three times washed with sterilized distilled water. Finally observation of stem rot mortality were recorded at 35-40 days after sowing and analysed statistically.

\section{Statistical analysis}

The experimental results were recorded and analysed by using WASP (Web Agri Stat Package). The data with percentage values were transformed into arc sine at critical difference at $5 \%$ significant levels.

\section{Classification of disease reaction}

The observations on disease intensity were recorded by using 0-7 grade score card as per Handle (2001) and Gaikwad (2002). Infectious lesions are produced by the pathogen under the stem, bulb and leaves. According to the disease intensity the ranking from immune to highly susceptible was done for every tuberose variety.

\section{Results and Discussion}

To ascertain the resistance / tolerance in tuberose cultivars against stem rot or basal stem rot, the experiment was conducted in pot culture under glass house condition.

The experimental result of six different cultivars of tuberose were studied for varietal screening against Sclerotium rolfsii, the single Mexican variety are found lower per cent disease incidence (55.55) followed by hybrid Prajwal found (66.66) when compared with other cultivars namely Suvasini (77.77), Thovalai local (88.88), Salem local (88.88), Dharmapuri local (88.88). all the cultivars were found susceptible (S) to stem rot or basal stem rot diseases but some cultivars (single Mexican and hybrid Prajwal) are found low level of infection or per cent disease incidence. 
The study suggests that all the six different cultivars of tuberose studied for varietal screening against Sclerotium rolfsii were found highly susceptible (HS) to basal stem rot disease.but some other cultivars are found low level of infection or per cent disease incidence compared with other cultivars namely the single Mexican variety (55.55) followed by hybrid Prajwal found (66.66) when compared with other cultivars. Similar research on various plants screened against some of the plant pathogens have been reported by various researchers. Swapnil Konde et al., (2017) studied varietal resistance of 16 soybean varieties against root rot and collar rot disease. Six varieties were moderately susceptible and ten were found highly susceptible to collar rot diseases. Pancheshwar et al., (2016) reported the screening of 77 soybean cultivars against collar rot disease and Sugha et al., (1991) evaluated 210 chickpea cultivars and observed that none of the varieties were found moderately resistant or resistant. Palaiah et al., (2019) evaluated 64 different germplasm and 33 ground nut varieties against the stem rot disease. Out of 64 germplasm, six germplasm showed moderate resistance and out of 33 groundnut varieties, 20 varieties showed moderate resistance.

Table.A Disease Reaction

\begin{tabular}{|c|c|c|c|}
\hline $\begin{array}{l}\text { Disease } \\
\text { index }\end{array}$ & $\begin{array}{c}\text { Stem/leaf } \\
\text { base area } \\
\text { infection } \\
\text { (PDI) }\end{array}$ & Symptoms & Infection reaction \\
\hline 0 & - & Nil & Immune (I) \\
\hline 1 & $<1$ & $\begin{array}{l}\text { About } 5 \% \text { area of the stem/bulb showing brown } \\
\text { discolouration }\end{array}$ & $\begin{array}{l}\text { Highly Resistant } \\
\text { (HR) }\end{array}$ \\
\hline 2 & $1.01-10.0$ & $\begin{array}{l}\text { About } 15 \% \text { area of the stem/bulb showing } \\
\text { brown discolouration }\end{array}$ & Resistant (R) \\
\hline 3 & $10.01-20.0$ & $\begin{array}{l}\text { About } 35 \% \text { area of the stem/bulb showing } \\
\text { brown discolouration, with mycelial mat } \\
\text { intermingled with few sclerotia. }\end{array}$ & $\begin{array}{l}\text { Moderately } \\
\text { Resistant (MR) }\end{array}$ \\
\hline 4 & $\begin{array}{l}20.01- \\
30.01\end{array}$ & $\begin{array}{l}\text { About } 50 \% \text { area of the stem/bulb showing } \\
\text { brown discolouration, with mycelial mat } \\
\text { intermingled with moderate sclerotia. }\end{array}$ & $\begin{array}{l}\text { Moderately } \\
\text { Susceptible (MS) }\end{array}$ \\
\hline 5 & $\begin{array}{l}30.01- \\
40.01\end{array}$ & $\begin{array}{l}\text { About } 75 \% \text { area of the stem/bulb showing } \\
\text { brown discolouration, with mycelial mat } \\
\text { intermingled with profuse sclerotia. }\end{array}$ & Susceptible (S) \\
\hline 6 & $\begin{array}{l}40.01- \\
50.01\end{array}$ & $\begin{array}{l}\text { About } 90 \% \text { area of the stem/bulb showing } \\
\text { brown discolouration, with mycelial mat } \\
\text { intermingled with profuse sclerotia. }\end{array}$ & $\begin{array}{l}\text { Highly } \\
\text { Susceptible ( HS) }\end{array}$ \\
\hline 7 & $>50.01$ & $\begin{array}{l}\text { About } 100 \% \text { area of the stem/bulb showing } \\
\text { brown discolouration, with mycelial mat } \\
\text { intermingled with profuse sclerotia. }\end{array}$ & $\begin{array}{l}\text { Highly } \\
\text { Susceptible ( HS) }\end{array}$ \\
\hline
\end{tabular}


Table.1 Reaction of tuberose cultivars to Sclerotium rolfsii infection in pot culture experiment

\begin{tabular}{|c|c|c|c|}
\hline SI.no. & Cultivars & Per cent mortality & Disease reaction \\
\hline 1 & Salem Local & $\begin{array}{c}88.88 \\
(78.05) a\end{array}$ & Highly susceptible (HS) \\
\hline 2 & Single Mexican & $\begin{array}{c}55.55 \\
(48.24) a\end{array}$ & Highly susceptible(HS) \\
\hline 3 & Dharmapuri local & $\begin{array}{c}88.88 \\
(78.05) a\end{array}$ & Highly susceptible(HS) \\
\hline 4 & Suvasini & $\begin{array}{c}77.77 \\
(71.56) a\end{array}$ & Highly susceptible(HS) \\
\hline 5 & Prajwal & $\begin{array}{c}66.66 \\
(59.90) a\end{array}$ & Highly susceptible(HS) \\
\hline 6 & Thovalai Local & $\begin{array}{c}88.88 \\
(78.05) a\end{array}$ & Highly susceptible(HS) \\
\hline 7 & control & $\begin{array}{c}00.00 \\
(0.28) \mathrm{b}\end{array}$ & Control plants \\
\hline & $\mathrm{CD}(0.05)$ & 36.85 & \\
\hline
\end{tabular}

* Mean of three observations; The treatment means are compared using Duncan multiple range test (DMRT) values in parentheses are arcsine transformed

In a column, mean followed by a common letter $(\mathrm{S})$ are not significantly different $(\mathrm{p}=0.05)$

\section{Sclerotial germination}
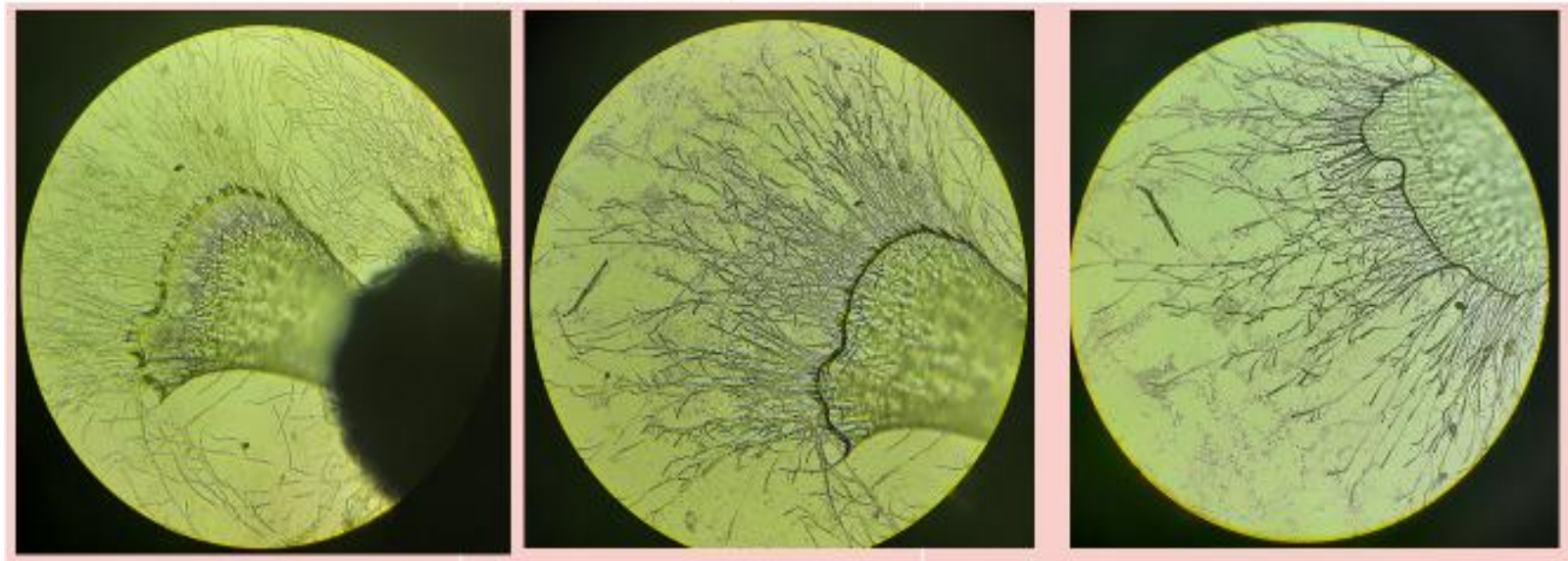

Fig.1 Microscope view of Sclerotium germination 

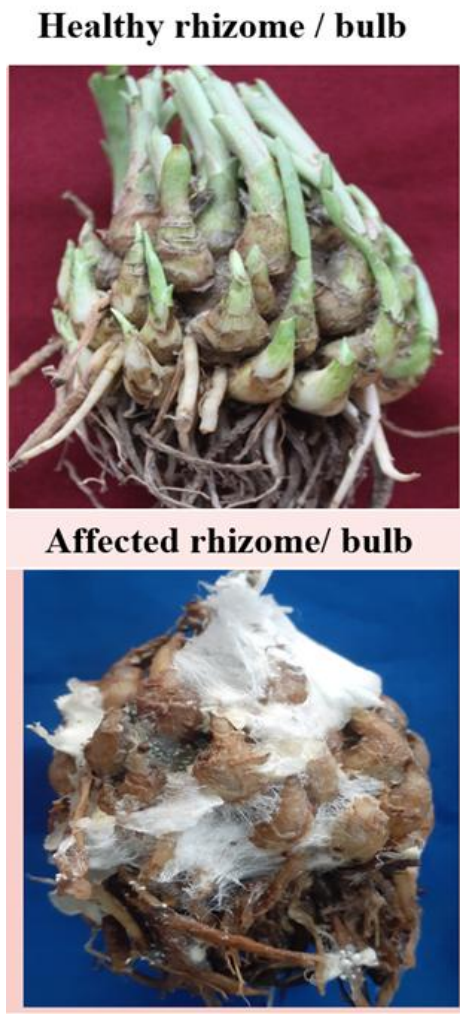

Fig.2 Tuberose bulb rot symptoms and pure culture of Sclerotium rolfsii

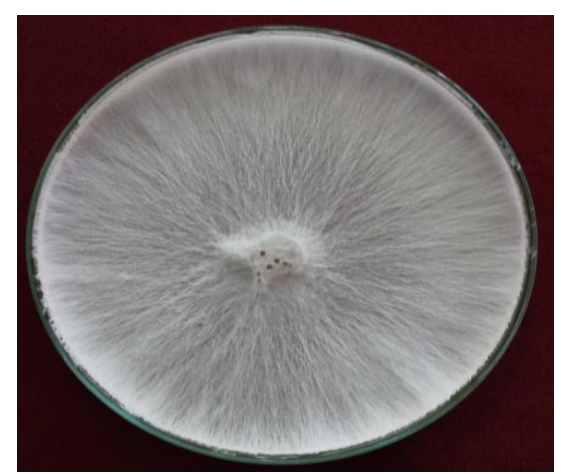

Pure culture

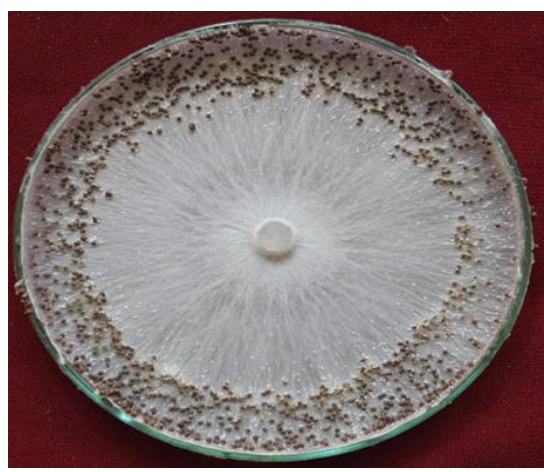

Pure culture + sclerotial bodies

Fig.3 Mass Multiplication of Sclerotium rolfsii

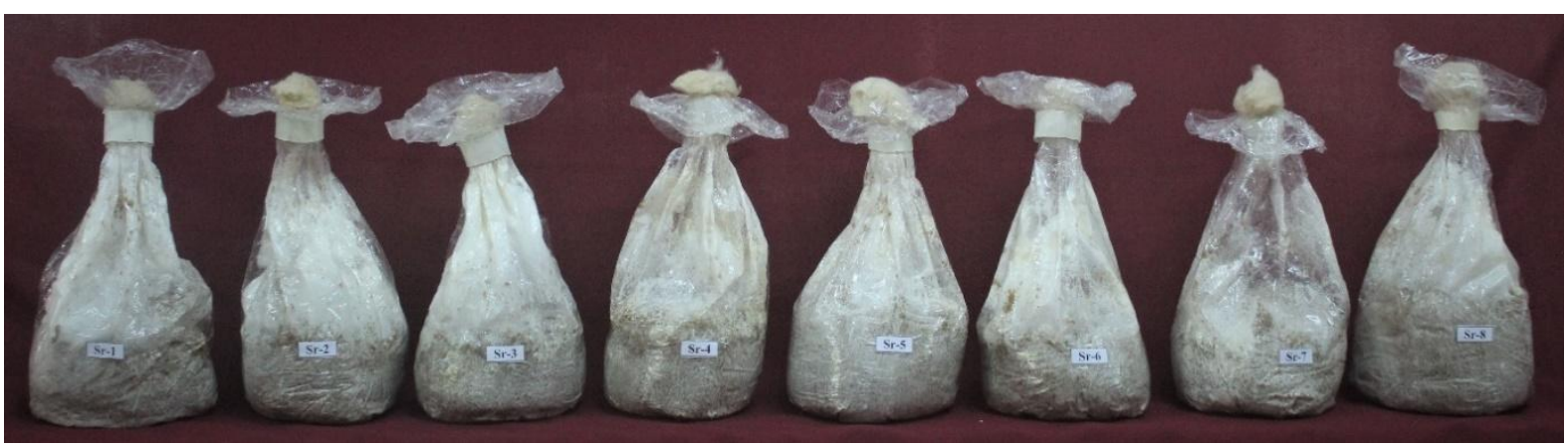

Fig.4 Sand Maize Medium 


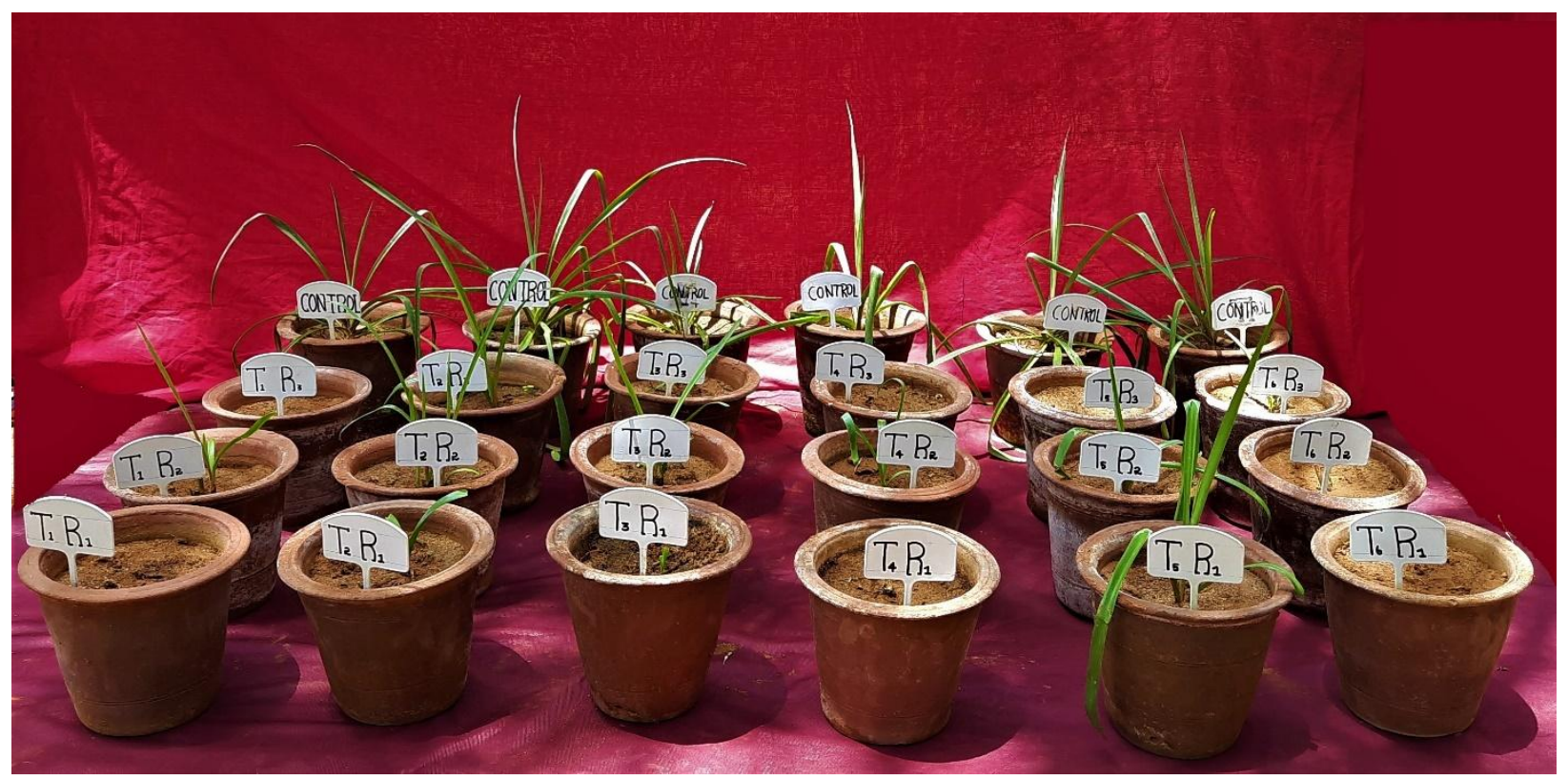

Fig.5 Reaction of tuberose cultivars to Sclerotium rolfsii infection in pot culture experiment

These findings suggest that all the cultivars are highly susceptible to the stem rot pathogen, But some other cultivars are found low level of infection or per cent disease incidence compared with other cultivars namely the single Mexican variety followed by hybrid Prajwal. So management of this disease should be done using this two different varieties followed by adapting various chemical or biological method to reduce the pathogen infection and increase the production and productivity of tuberose.

\section{Acknowledgements}

This research was supported by the Department of Plant Pathology, Tamil Nadu Agricultural University AC \& RI, Killikulam628252 Thoothukudi, (India) and Floriculture research station (Thovalai) Kanyakumari.

\section{References}

Handle, J.M. (2001). Studies on leaf spot of curry leaf (Murraya Koenigii). M.Sc. (Agri.) Thesis submitted to M.P.K.V.,Rahuri, Maharashtra, India.
Hutchinson, J. 1944. The Families of Flowering Plants. II. Monocotyledons (Agavaceae) : 151-154.

Hutchinson, J. 1959. The Families of Flowering Plants $\left(2^{\text {nd }}\right.$ ed. $)$ vol.2. Monocotyledons (Agavaceae) : 662665.

Hutchinson, J. 1960. The Families of Flowering Plants. Clarendon Press, Oxford.

Maliga L (2003) Tantalizing tuberose. The chamomile times and herbal news.

Mallavarapu GR (1995) Essential oils from some aromatic ornamental plants. Ornamental plants Eds: Advance in Horticulture 12: 1046.

Palaiah, P. Narendrappa. T and Mallesh S.B. (2017). Screening of groundnut varieties and germplasm against collar rot, stem rot and dry root rot disease. (Plant pathology),ICAR-Krish Vigyan Kendra, Raddewadagi, Kalaburgi- 585 310, India.

Pancheshwar, D.K., R.K. Varma, G. Singh and S.Mehra. (2016). Screening of Rhizoctonia bataticola isolates against soybean cultivars for source of 
resistance. International journal of agricultural science. 8(2): 952-954.

Randhawa, GS, Mukhopadhyay A (1986)

Tuberose. In: Floriculture in India.

Allied Publishers Private Limited, New Delhi 425-426.

Rose, J.N. 1903. Amaryllidaceae. Contribution from the United States National Herbarium. 8: 8-23.

Rose, J.N. 1903-1905. Studies of Mexican Central American Plants. Contribution from the United States National Herbarium, 8 : 1-55.
Sugha, S.K., B.K. Sharma and P.D. Tyagai. (1991). A modified technique for screening chickpea varieties against collar rot caused by sclerotium rolfsii. International journal of agricultural science, 61(4): 289-290.

Swapnil Konde, Rajkumar Kothikar, Mina Koche and Amit Surpam. (2017). Studies on varietal resistance in soybean against root rot and collar rot diseases. Innovative farming,2(2): 108-110.

\section{How to cite this article:}

Boopathi. P., M. Jayasekhar, N. Rajinimala, M. Gomathy and Prem Joshua. J. 2020. Studies on Varietal Reaction of Tuberose against Stem Rot Diseases Caused by Sclerotium rolfsii. Int.J.Curr.Microbiol.App.Sci. 9(07): 665-671. doi: https://doi.org/10.20546/ijcmas.2020.907.076 